Hervé Boulhol*

\title{
Towards a Universal Pension Points System in France
}

The current French pension system offers good social protection, translating into high average relative incomes and low relative poverty among the elderly. However, it is deeply fragmented and its structure is overly complex. The objective of the planned reform is to simplify the system substantially, improve its management, reduce inequalities in the rules used to compute benefits and facilitate labour mobility. The reform aims at introducing a universal points system, thus eventually eliminating special regimes. Several OECD countries have a points system: contributions are used to purchase points, and at retirement the pension is equal to the sum of acquired pension points multiplied by the point value.

The creation of a universal pension regime in France is a major reform. Previous reforms have improved financial sustainability. As there has been suspicion that the planned measures would be used to lower pensions further, the emphasis was on budget-neutral reform. However, it quickly became apparent that such a big overhaul defining the way the old-age social protection system will work in the future could not be undertaken without addressing financial sustainability.

Ideally, two reforms were needed, but both dimensions were included in the same draft law. The first reform is the design of the universal system, in which pension rights will be included in the new system from 2022-2025 and the first generation will retire with these points as part of their pension in 2037. The second is the parametric measures aimed at ensuring the financial balance of the current system in 2027. This second component is totally distinct from the implementation of the universal system and

(C) The Author(s) 2020. Open Access: This article is distributed under the terms of the Creative Commons Attribution 4.0 International License (https://creativecommons.org/licenses/by/4.0/).

Open Access funding provided by ZBW - Leibniz Information Centre for Economics.

* This article does not represent the official views of the OECD or of its member countries. The opinions expressed and arguments employed are those of the author. The author is grateful to Maciej Lis and Monika Queisser for very valuable comments.

Hervé Boulhol, Organisation for Economic Co-operation and Development, Paris, France. could have happened in the absence of systemic reform if the political will had been such.

\section{Current French pension system}

Main schemes for private sector workers

A specificity of the current French system is that a private sector worker is currently covered by two mandatory public pay-as-you-go (PAYGO) schemes: a general defined benefit (DB) scheme - which is the main component - managed by the state and a points scheme (AgircArrco) managed by social partners, together representing about $70 \%$ of paid benefits. The other $30 \%$ comes from special regimes, including those covering civil servants. To get a full pension in the DB component, individuals must be older than 62 years and have contributed for 41.5 years ( 43 by 2035) or be older than 66 (67 in 2022) years. Contribution rates are relatively high in France, the average age of labour market exit is low and pension spending is high at about $14 \%$ of GDP (OECD, 2019a). Reforms over the last decades have increased both contribution rates and retirement ages, and lowered replacement rates (OECD, 2019b).

The majority of OECD countries take into account wages throughout the whole career for pension calculation. Today, for private sector workers, only Austria, France, Slovenia, Spain and the United States take into account only part of the career (Figure 1). In Austria, lifetime earnings will apply for the generations born from 1955.

The current reference wage for private sector workers is based on the best 25 years of earnings, while for civil servants it is the wage over the last six months. Taking into account the full career is both more transparent and equitable. While taking into account only the best years protects against some forms of career breaks, it also generates perverse, regressive effects by favouring workers experiencing large wage improvements (Aubert and Duc, 2011).

In France, both replacement rates and pension financial balances are highly dependent on real-wage growth. This dependence stems from the price uprating of past wages in the general scheme - formalised by the 1993 reform the price indexation of the cost and the value of the point, which has often been applied discretionally in the AgircArrco scheme, and the price indexation of pensions in 
Figure 1

Few OECD countries take into account wages for only part of the career

number of years used to compute the reference wage

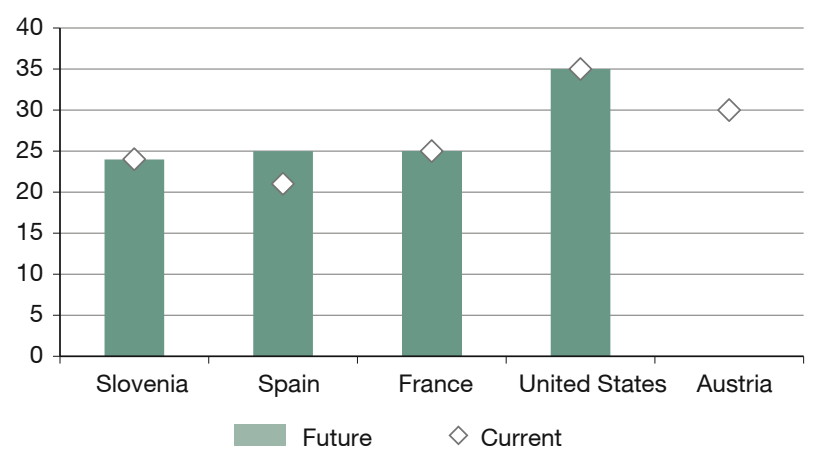

Source: OECD (2019), Pensions at a Glance, OECD Publishing.

payments. Price uprating was chosen in 1993 because it was socially and politically more acceptable given the lack of understanding among the population of its implications for pension benefits.

\section{Complexity}

There are 42 mandatory pension schemes with very different rules. On average, each individual has currently contributed to more than three regimes, the benefits of which do not add up in a straightforward way. Even for private sector workers, France is unusual, as explained above.

Due to the complex interactions between the rules of the various schemes, issues raised by workers affiliated with different regimes often become serious obstacles to the needed reforms that modify some parameters in some schemes. These interactions are also a serious hurdle for the overall management of the system, as the envisaged policy measures only have partial effects. Yet, each of these partial reforms carries some political costs and their needed recurrence gives the impression that pensions require some endless adjustments. Moreover, the overall complexity makes it very difficult for contributors to correctly anticipate their retirement income, which in turn makes it hard to take adequate retirement decisions.

\section{Fragmentation}

The fragmentation of the system implies substantial differences in the treatment of workers in the private sector, the public sector, those covered by numerous special regimes and the self-employed. Despite recent harmonisation measures, large inequalities result from differences in the rules used to compute benefits including those that apply to survivor pensions - which alone are covered by 13 additional different regimes. These differences also create a suspicion that other workers in other sectors are better treated. In turn, this suspicion fuels the motivation to defend one's own interests and complicates the implementation of policies to improve the system and reduce unequal treatment. Strong opposition to the reform has come from workers covered by schemes that would ultimately disappear, such as those covering employees in the railway sector, energy and subway companies and some self-employed groups.

One historical reason for a preferential treatment in the public sector may be the result of the need to attract civil service workers, a need that has vanished over time. These views also refer to the career being considered a lifelong job; in the absence of mobility, civil service pensions in particular were therefore best organised in a stand-alone system and could have been considered deferred compensation. A job for life, however, is a thing of the past.

France is one of only four OECD countries, along with Belgium, Germany and Korea, that still has totally different schemes covering private and public sector workers. The differences in pension benefits between public and private sector workers with similar earnings can be significant in France - although much lower than in the other three countries (OECD, 2016). Moreover, the heterogeneity of rules in France also applies within the public sector, where there are wide differences (Conseil d'orientation des retraites [COR], 2018).

In half of the OECD countries, all employees are covered under the same mandatory schemes at least for new labour market entrants. Ten countries have a fully integrated scheme, but with a top-up component for civil servants above and beyond the mandatory schemes that exist for private sector workers. The difference of benefits between public and private sector workers with similar earnings thus depends on the level of the top-up. It is within these countries that the largest OECD differences are found: this is in particular the case in Canada, the United States and the United Kingdom (OECD, 2016).

Teachers are a case in point in France. They benefit today from a higher pension than private sector workers with similar earnings throughout the career. This might be seen as a compensation for low wages. Indeed, in international comparison, teachers' wages tend to be low in France, especially in the first part of the career. With the reform, teachers would lose in terms of pensions as a result of unifying pension rules. The reform actually reveals serious issues in the wage formation of teachers, which pension schemes are ill equipped to address. The problem thus lies in the wage setting process, and while the govern- 
ment intends to increase teachers' wages, the overall effect will be seen in the long term through the combined action of future governments.

\section{Core of the current reform: Simpler and more equitable}

The French government created the High Commission for Pension Reform in September 2017 to prepare the reform introducing a universal pension points system in France. In July 2019, the High Commission published its recommendations entitled For a universal pension system, simpler, fairer, for all. In January 2020, a draft law was adopted by the Council of Ministers and is being discussed in parliament as of February 2020. Pension entitlements in the new system would start to accrue gradually from 2022 for those born in 2004 and from 2025 for all individuals born from 1975.

The unified pension system aims to establish common rules for contributions and the calculation of pension entitlements for all workers, drastically simplify the current system, and ensure financial sustainability by reducing the sensitivity of financial balances to economic and demographic trends and short-term shocks.

The reform aims at introducing a universal PAYGO points system based on some key principles:

- All 42 regimes will be included based on common rules and replaced by the universal points system;

- Financial stability and sustainability should be ensured, and in particular the system should be designed such that it is resistant to economic and demographic shocks;

- Pension entitlements will accrue up to a wage ceiling of three times the social security (annual) ceiling (PASS);

- The minimum retirement age will be maintained at 62 ;

- Points will be allocated for each child and for career breaks (related to unemployment, maternity leave, sickness, disability, etc.), and specific situations will be accounted for (long careers, arduous and hazardous work, handicaps);

- The system will include a survivor and a minimum pension scheme.

Points schemes and comparison with countries having a points or NDC scheme

Publicly provided earnings-related pension schemes are typically PAYGO and follow three broad types: defined benefit (DB), points and notional (non-financial) defined contribution (NDC). The 42 mandatory public pension schemes in France mix DB and points schemes, with different rules in each broad category. With the planned reform, France made the clear choice to keep the core of the pension system as a public PAYGO. The new system would be based on a points system for the unified framework.

A generic NDC system is appealing technically because it is designed to ensure financial stability. The counterpart of this financial robustness is twofold. First, cohorts that live longer have, as a rule embedded in the system, to contribute for longer periods to maintain replacement rates at similar levels to older cohorts. Second, for given contribution rates, a generation that relies on a fast growing (declining) working-age population will benefit from higher (lower) replacement rates. This second implication is inherent in PAYGO systems whereby current workers directly finance current pensioners, but it is automatically included in generic NDC schemes. The main shortcoming of NDC might lie in the difficulty workers have to grasp the concept of notional accounts, how accounts evolve over time and what they concretely imply for the level of benefits (Sundén, 2013).

The choice of constraining rules reflecting trends in wages, employment and life expectancy is therefore critical for the good management of the system. Depending on how uprating and indexation rules are defined, there could be some equivalence between points schemes, DB schemes and NDC schemes (Boulhol, 2019). A strict equivalence in the benefit formula between a points and an NDC scheme holds if:

- There is a static condition for a given cohort: the indexation rate of the cost of purchasing a point is equal to the notional interest rate, which in its generic form is equal to the growth rate of total contributions.

- There is a dynamic condition across cohorts: the value of the point at a given (retirement or reference) age has to be indexed to the notional interest rate minus the growth rate of remaining life expectancy at retirement age. On average across OECD countries, remaining life expectancy at 65 is projected to grow by $0.47 \%$ per year on average by 2050 and by $0.42 \%$ in France.

Nine OECD countries have introduced a points or NDC system at the core of their public pensions since the early 1990s. Table 1 summarises how countries implicitly uprate past wages, index pensions in payments, account for employment trends and changes in longevity within their points or NDC scheme. Uprating past wages are embed- 
Table 1

Rules for pension entitlements, initial benefits and indexation

Points and NDC schemes

\begin{tabular}{|c|c|c|c|c|}
\hline Country & Type & $\begin{array}{l}\text { Uprating of past wages (cost of } \\
\text { points/valorisation of notional } \\
\text { accounts) }\end{array}$ & $\begin{array}{l}\text { Initial pension (point value / life } \\
\text { expectancy (LE) link) }\end{array}$ & $\begin{array}{l}\text { Indexation of pensions } \\
\text { in payment (point value) }\end{array}$ \\
\hline (1) & (2) & (3) & (4) & (5) \\
\hline Estonia & Points & Wages & Mix wage bill and prices & Same as (4) \\
\hline Germany & Points & Wages & Wages + adjustment factors & Same as (4) \\
\hline Italy & NDC & GDP & Link with LE & Prices \\
\hline Latvia & NDC & Wage bill & Link with LE & Mix wage bill and prices \\
\hline Lithuania & Points & Wages & Wage bill & Same as (4) \\
\hline Norway & NDC & Wages & Link with LE & Wages - $0.75 \%$ \\
\hline Poland & NDC & Mix wage bill and GDP & Link with LE & Mix wages and prices \\
\hline Slovak Republic & Points & Wages & Wages & Mix wages and prices \\
\hline Sweden & NDC & Wages + balancing mechanism & Link with LE & (3) $-1.6 \%$ \\
\hline Agirc-Arrco & Points & Discretionary & Discretionary & Discretionary \\
\hline $\begin{array}{l}\text { Draft law, universal } \\
\text { points system, France }\end{array}$ & Points & $\begin{array}{l}\text { Income per capita } \\
\text { after transition phase }\end{array}$ & $\begin{array}{l}\text { Income per capita } \\
\text { after transition phase }\end{array}$ & Price \\
\hline
\end{tabular}

Source: Based on Boulhol, H. (2019), Objectives and challenges in the implementation of a universal pension system in France, OECD Economics Department Working Papers, No. 1553.

ded in rules governing points and NDC schemes through the indexation of point cost and the chosen NDC interest rate, respectively.

On one extreme, rules can be closely related to actuarial principles and sustainable returns. On another extreme, there can be a total discretion left to the managers, such as in the Agirc-Arrco scheme, which limits transparency and perhaps confidence in the system.

Changes in life expectancy are automatically embedded in the computations of the initial pension in countries with NDC systems. Changes in the size of the labour force are not reflected in many countries covered in Table 1, which makes their system less stable (Auerbach and Lee, 2009), generating the need for another instrument to adjust benefits and/or finances. Within points schemes, Germany accounts for employment and demographic trends in the point value through the sustainability factor, which depends on the ratio of pensioners to contributors.

In France, while the minimum retirement age is maintained at 62 years, a reference age (âge d'équilibre) will be introduced to serve as the retirement age at which the point value is computed for a given birth cohort. People of the same cohort but retiring earlier or later would have a penalty or bonus applied to this value, respectively. According to the draft law, the reference retirement age would be linked to life expectancy, with two-thirds of changes in life expectancy being passed on. Pensions in payments will be indexed to prices. The cost and value of the point would be indexed to the average income per capita (i.e. accounting for both wages of employees and incomes of self-employed workers) from 2045, after a transition phase starting with price indexation in 2025. It would have been preferable to follow the (long-term) rule from the start and adjust the initial point cost and point value accordingly.

\section{Transition}

The impetus for the systemic reform in these nine countries often stemmed from the need to make pensions financially sustainable given ageing prospects. These countries already had a fairly integrated system, except Italy, which unified the system with the introduction of the NDC scheme, and Germany, which did not tackle that aspect.

In terms of transition, Germany is a special case because the system basically functioned like a points-based scheme before the reform. The reform was very fast in the Baltic countries and in the Slovak Republic. In Sweden and Norway, the implementation started about five years after being legislated with a transition of 10 to 15 years. In Italy, the new NDC system gradually applied across 20-25 yearly cohorts. In France, it will be across 30 cohorts, as the individuals born in 1975 would be the first generation accruing some entitlements in the new system, and those born in 2004 would be the first to have accrued all their pension rights in the new scheme. 
Another factor influencing the length of the transition refers to the number of years until the first affected cohort retires. In Sweden, individuals who were age 60 at the time of the voted reform were affected as $20 \%$ of their pension was computed based on entitlements converted in the new scheme. In Norway, this applied to those who were 58 years of age, while in Italy it applied to those who were about 38 years old. In France, it will be 45 years old, i.e. the age of those born in 1975 at the expected time of the vote of the reform (2020).

Finally, the question of the conversion of acquired rights is critical. In Sweden and Norway, there has been a conversion of entitlements in the new scheme based on a weighting depending on the birth year, hence a mixed system for 15 years in Sweden and ten years in Norway. By contrast, Italy has been going through a very long process as there has not been any conversion, hence a very long transition of 45-50 years after the adoption of the reform. In France, the government decided in February 2020 that there will be no conversion of rights acquired in old schemes. Benefits from entitlements accrued before the implementation of the new system (2022-2025) will be computed at the time of retirement based on all the rules of each regime, implying that these rules will continue to apply, albeit with a decreasing weight, until about 2065. This means that the generations born until 2004 will not benefit from the simplified calculation of what they can expect for their total pension.

\section{Financial balance}

\section{Balancing the current system}

As part of the reform, the objective of ensuring the financial balance of the overall pension system by 2027 is now included. Given the complexity of the system, assessing the financial situation of the system is in itself a complex task. In November 2019, the Conseil d'orientation des retraites at the government's request published a report about the 2030 pensions outlook in France (COR, 2019). Depending on assumptions related to real-wage growth and, more importantly, to the chosen accounting rules, the current pension system shows a projected deficit in 2030 between $0.3 \%$ and $1 \%$ of GDP.

To eliminate the deficit by 2027 , the government intended to introduce a new penalty when retiring before an 'equilibrium age' that would have gradually increased from 62 years and four months in 2022 to 64 years in 2027. However, it eventually decided to open the possibility of alternative measures based on an agreement between social partners. The latter should make proposals by the end of April 2020. Their mandate is constrained though as the proposed measures should focus on increasing effective retirement ages given that the draft law refers to measures that will lead to neither lower pensions nor higher labour costs.

\section{Adjustment mechanisms in the new system}

Pension systems cannot be managed on 'autopilot' as there are always unpredictable events that affect pension levels and finances. Hence, although it is important to design the rules in a way that best accounts for future trends and that is conditional on the exact (albeit initially uncertain) scope of these trends, additional adjustment mechanisms are needed.

Among the nine countries in Table 1, only Germany and Sweden have implemented additional adjustment rules (Boulhol, 2019). In Germany, the contribution rate must be increased if the pension account balance - taking the sustainability factor into consideration - deteriorates beyond a certain threshold, which in turn automatically lowers the point value (that is indexed to net wages), thereby sharing the burden of the adjustment between current workers and current pensioners. One significant difference from the Swedish mechanism is that the adjustment is triggered based on short-term liquidity imbalances and not on the estimated long-term solvency of the system.

Sweden directly adjusts pension entitlements and benefits to ensure solvency, based on current pension liabilities and assets made of contribution assets and (the market value of) the buffer fund. The buffer fund represents around $30 \%$ of GDP. An automatic balancing mechanism is applied when the calculations imply a potential deficit. In that case, a brake is activated, as it was initially in 2010 based on 2008 values, reducing the notional interest rate below the wage growth rate in order to both limit accumulation in notional accounts and reduce indexation of pensions in payments. By contrast, there is no balancing mechanism in Norway, and the general government budget backed by the national wealth fund remains the shock absorber.

A balancing mechanism is a valuable tool, but even Sweden experienced some difficulties in applying the brake rule. In that sense, the economic and financial turmoil provided a stress test. The adjustment implied by the rule would have amounted to a real-term reduction of $4.6 \%$ in pensions and was considered so large that policymakers decided to spread it out over a longer period (Sundén, 2009). Overall, the Swedish mechanism proved resilient, only requiring a small adjustment. As a result, its broad principles remain largely unchallenged even though the experience shows 
that in periods of large volatility, interventions by politicians are still needed (Weaver and Willén, 2014).

In France, the draft law introduces a golden rule, according to which in each year $t$ the five-year projected balance cumulated over $t$ and $t+4$ cannot be negative. Focusing on a cumulated indicator (stock concept) is welcome as the target is often to reach a yearly balance (flow concept), implying that past deficits are not corrected and therefore increase debt. However, the objective of this type of mechanism should be to ensure the long-term balance, and five years is not a long period to cover a full economic cycle. This might imply the need to take pro-cyclical measures to respect the golden rule, thereby amplifying the impact of short-term shocks.

It seems that the choice of a fairly short period was guided by the fear that adjustments might be deferred for too long. Even with the proposed design, there is always the risk that needed measures are deferred to year $t+3$ or $t+4$. These are complex issues when there is a limited track record of fiscal discipline that would provide some initial credibility. Hence, there is no easy answer. The best option would be to focus on the real objective, a sane long-term financial management with two options. Simple rules should be designed and enforced, but it is not clear whether, even with the simpler universal points system, they can be defined to meet this objective. Otherwise, this mandate should be given to an independent institution, which would propose a menu of corrective actions as needed.

One central issue for the management of public PAYGO pension systems, and of points and NDC schemes in particular, refers to how pension accounts are clearly separated or even ring-fenced from the other components of general government balances. The credibility of a golden rule would be enhanced by ring fencing pension accounts.

\section{Conclusions}

The OECD has long supported the principle of a universal pension system in France. The current system provides effective social protection for current retirees, but it is overly complex and generates significant differences in the treatment of various population groups. This also leads to serious complications in both the coordination of the large number of different schemes and the management of the overall system. The main goal of the reform is to simplify the system and treat everyone equally. On top of systemic changes, the reform aims at ensuring the financial balance of the current system by 2027.

This reform will eliminate or substantially reduce some significant shortcomings of the current system, including the sensitivity of replacement rates and pension finances to long-term productivity growth, unintended forms of redistribution due to the complex interaction of rules and the fact that only parts of the career are taken into account to calculate pension entitlements. Actually, it will do this in the long term only, as France opted for a very long transition, which will delay the benefits of the reform. The long transition is due to both applying the reform to those born from 1975 on only (instead of 1963 as initially envisaged) and not converting entitlements acquired in the current schemes as Italy had done.

In this context, it is important to put in place clear indexation rules applying to the cost and the value of points as well as pensions in payments. Those rules should be completed by a balancing mechanism that focuses on fiscal discipline, i.e. in a credible way to ensure long-term cumulated financial balances, while preserving a high enough level of pensions.

Given population ageing, it is crucial to raise effective retirement ages, especially in France, where employment of older workers and the average age of the labour market exit are low. The planned reform defines an 'equilibrium' retirement age, which will be used as a reference for the point value and increase (decrease) based on two-thirds of life expectancy gains (losses).

\section{References}

Aubert P. and C. Duc (2011), Les conséquences des profils individuels des revenus d'activité au long de la carrière, Economie et Statistique, No. 441-442, 159-186.

Auerbach, A. J. and R. Lee (2009), Notional Defined Contribution Pension Systems in a Stochastic Context: Design and Stability, in J. Brown, J. Liebman and D. Wise (eds.), Social Security Policy in a Changing Environment, National Bureau of Economic Research Conference Report.

Boulhol, H. (2019), Objectives and challenges in the implementation of a universal pension system in France, OECD Economics Department Working Papers, No. 1553.

Conseil d'orientation des retraites (2019), Perspectives des retraites en France à l'horizon 2030, COR.

Conseil d'orientation des retraites (2018), Rapport annuel, COR.

OECD (2019a), Pensions at a Glance, OECD Publishing.

OECD (2019b), Will future pensioners work for longer and retire on less? OECD Policy Brief on Pensions, OECD Publishing.

OECD (2016), Civil service pension: Toward a unified system with the private sector, in OECD, Pensions Outlook, Chapter 6, OECD Publishing.

Sundén, A. (2009), The Swedish pension system and the economic crisis, Issue in Brief, No. 9-25, Center for Retirement Research at Boston College.

Sundén, A. (2013), The Challenge of Reaching Participants with the Message of NDC, in R. Holzmann, E. Palmer and D. Robalino (eds.), Nonfinancial Defined Contribution Pension Schemes in a Changing Pension World, Volume 2, 257-272.

Weaver, K. and A. Willén (2014), The Swedish pension system after twenty years: Mid-course corrections and lessons, OECD Journal on Budg eting, 13(2), 1-26. 